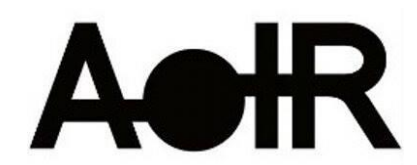

Selected Papers of \#AoIR2021:

The 22nd Annual Conference of the

Association of Internet Researchers

Virtual Event / 13-16 Oct 2021

\title{
SHARED NETWORKS: THE PATHS OF LATIN-CENTRIC INDIGENOUS NETWORKS TO A PLURIVERSAL INTERNET
}

\author{
Fernanda R. Rosa
}

Virginia Tech

The sun was already setting when we were leaving the neighborhood of San Martín in Abasolo. The internet was now finally working in one of the houses of that Tseltal pueblo for the first time. The area was densely green, in a hill with sparse houses, some of them not that distant from each other, denoting the sharing of land by family members. The state of Chiapas, Mexico, where this pueblo is located, is ranked at the lowest level of internet connectivity in the country. In the role of a doctoral researcher, I was joining a group of indigenous activists, part of the Colectivo I $k^{\prime} T a K^{\prime} o p$ (Word of the Wind Collective) in Abasolo, in the town of Ocosingo, whose goal is to expand internet access in their community.

This paper is an invitation to understand the global internet interconnection infrastructure, focusing on the strategies of Tseltal and Zapoteco communities to become part of the internet. Deciding to improve their connectivity conditions marked by poor or absent internet services in their territories, they have autonomously engaged in processes of "infrastructuring," by building their own internet networks and interconnection arrangements to physically connect to the larger internet.

I borrow the term "infrastructuring" from participatory design scholarship, where "information infrastructure is viewed as constantly 'becoming'," (Karasti, 2014, p. 3) in that design is a continuous activity, a "process of inscribing knowledge and activities in new material forms" (Karasti, 2014, p. 3 emphasis added). Focusing on Tseltal and Zapoteco internet design experiences, this paper aims to address the internet ecosystem with a bottom-up approach, seeking to shed light on the role of infrastructure in this scenario and raising, at least, two points.

First, it calls attention to the existence of shared networks, built by indigenous people, but non-discernible when seen from above. From an internet routing system standpoint, networks are owned by autonomous systems and identified with autonomous system numbers (ASNs). That is not the case of the indigenous networks studied here, as they interconnect to internet service providers as a mere household, becoming part of that

Suggested Citation (APA): Rosa, Fernanda R. (2021, October). Shared Networks: The Paths of LatinCentric Indigenous Networks to a Pluriversal Internet presented at AolR 2021: The 22nd Annual Conference of the Association of Internet Researchers. Virtual Event: AolR. Retrieved from http://spir.aoir.org. 
commercial network without their own ASN. As already noted, "the question is perhaps not just what is a network but what it means to treat something as one" (Dourish, 2017, p. 172). Despite their invisibility, Tseltal's and Zapoteco's shared networks are internet networks.

Second, these shared networks illuminate processes of Latin America hybridization and ${ }^{c}{ }^{\prime} i x i,{ }^{1}$ only recognized when adding the lens and the values of these communities to the discussion. When they decide to be part of the internet, they ally with technologies and create interconnection arrangements that mark the instant when their local networks become part of the global internet. At the moment of interconnection, when the local becomes global, the values embedded in their actions and technology allies, here discussed in terms of comunalidad scholarship (communality, own translation), meet the values of the internet service providers regulated by their policy terms, materializing hybrids and ch'ixi, an articulation of intentions and negotiations that make that internet possible. And while framing indigenous media as a hybrid is not new (Ginsburg, 1991), framing the moment of internet interconnection as the moment when it materializes allows to think in terms of both the "technopolitics" of interconnection, and the materialization of hybridization and ch'ixi into infrastructure in the specific context of Latin America (Canclini, 1989; Cusicanqui, 2012).

Thus, I adopt the term shared network to denote the internet first mile signal-sharing practices that articulate both interconnection infrastructure and coexistence values to extend basic services to underserved areas, here in particular, to extend the internet to areas where the services of existing larger internet service providers are unsatisfactory or unavailable. Shared networks both acknowledge the sharing-oriented principles characteristic of these networks, independent of the actor responsible for it (a municipality, a collective, a business, etc.), while also critically illuminating interconnection infrastructure that affords and materializes such principles. It takes into consideration that artifacts are actively constitutive of societies' morality (Latour, 2008), implying a delegation of their values to infrastructure.

The shared network in Guelatao is presented in the paper focusing on the formation and design of their first mile infrastructure, followed by the case in Abasolo, which is presented complementarily with a focus on the sharing principles that they expand inside the community. Joining literature focused on actors whose participation still need to be told and emphasized (Costanza-Chock, 2020; Mcllwain, 2019), in considering the internet design as a process, the present research enable to see Tseltal's and Zapoteco's participation clearly, as internet codesigners. Furthermore, in identifying these shared networks as Latin-centric indigenous networks, this paper calls attention to similar patterns of colonialism and coloniality rooted in Latin American history and entangling the sovereign territories of Tseltal and Zapoteco people. Their protagonist role enables to see a vivid struggle for a pluriversal internet, founded on pluriversal (as opposed to universal principles (Escobar, 2018). An internet that is not homogenizing, but inclusive and diverse by design.

\footnotetext{
${ }^{1}$ Silvia Rivera Cusicanqui informs that the word ch'ixi "has many connotations: it is a color that is the product of juxtaposition, in small points or spots, of opposed or contrasting colors: black and white, red and green, and so on." (Cusicanqui, 2012, p. 105).
} 


\section{Methodology and Methods}

Considering that technology and society mutually shape and embed each other, I apply the ethnography of infrastructure (Star, 1999) to indigenous infrastructure projects in order to "learn from the South and with the South" (Santos, 1995, p. 508). The question this research endeavors to answer is "What do Tseltal's and Zapoteco's local networks add to our understanding of internet interconnection infrastructure?"

In the present paper, I examine two of the sites that I visited following the International Forum on Indigenous and Communitarian Media, in Oaxaca, in August 2017. The sites are a Tseltal pueblo in Abasolo, Ocosingo, in Chiapas, and a Zapoteco pueblo in Guelatao de Juárez, in Oaxaca, where I have conducted research since then.

\section{References}

Canclini NG (1989) Culturas Hibridas. Estrategias Para Entrar y Salir de La Modernidad. 1st Edition. Mexico City: Grijalbo.

Costanza-Chock S (2020) Design Justice: Community-Led Practices to Build the Worlds We Need. 1st Edition. Cambridge, MA: MIT Press.

Cusicanqui SR (2012) Ch'ixinakax utxiwa: A Reflection on the Practices and Discourses of Decolonization. South Atlantic Quarterly 111(1): 95-109. DOI: 10.1215/00382876-1472612.

Dourish P (2017) The Stuff of Bits: An Essay on the Materialities of Information. 1 edition. Cambridge, Massachusetts: The MIT Press.

Escobar A (2018) Designs for the Pluriverse: Radical Interdependence, Autonomy, and the Making of Worlds. Duke University Press.

Ginsburg F (1991) Indigenous Media: Faustian Contract or Global Village? Cultural Anthropology 6(1). [Wiley, American Anthropological Association]: 92-112.

Jasanoff S (ed.) (2004) States of Knowledge: The Co-Production of Science and Social Order. International library of sociology. London; New York: Routledge.

Karasti H (2014) Infrastructuring in Participatory Design. In: Proceedings of the 13th Participatory Design Conference: Research Papers - Volume 1, New York, NY, USA, 2014, pp. 141-150. PDC '14. ACM. DOI: 10.1145/2661435.2661450.

Latour B (2008) Where Are the Missing Masses? The Sociology of a Few Mundane Artifacts. In: Johnson DJ and Wetmore JM (eds) Technology and Society, Building Our Sociotechnical Future. 1st Edition. Cambridge, MA: MIT Press, pp. 151-180. 
Mcllwain CD (2019) Black Software: The Internet \& Racial Justice, from the AfroNet to Black Lives Matter. 1st Edition. Cambridge: Oxford University Press.

Santos B de S (1995) Toward a New Common Sense: Law, Science and Politics in the Paradigmatic Transition. 1 edition. New York: Routledge.

Star SL (1999) The Ethnography of Infrastructure. American Behavioral Scientist 43(3): 377-391. DOI: 10.1177/00027649921955326. 